\title{
Paydaş Yönetimi Yaklaşımı Doğrultusunda Kurumsal Sosyal Sorumluluk (KSS) ve Halkla İlişkilerin Rolï ${ }^{I}$
}

\author{
Corporate Social Responsibility (CSR) in Line with Stakeholder Management \\ Approach and the Role of Public Relations
}

\author{
Ayşe GEDIKKÇİ ÖNDOĞAN*
}

\begin{abstract}
$\ddot{O} Z$
İşletmelerin meşruiyet kazanmak adına toplumsal talep ve baskılar doğrultusunda hareket etmesi ve sosyal açıdan sorumlu bir vatandaş olduğunu göstermesi gereksinimi Kurumsal Sosyal Sorumluluk (KSS) çallşmalarına verilen değerin artmasına neden olmuştur. Temel düzeyde doğruluk, adalet ve dürüstlük sorumluluklarının yanı sıra çevreye, topluma ve özellikle paydaşlarına karşı çeşitli sorumlulukları bulunan işletmelerin paydaş beklentileri doğrultusunda hareket etmesi gereksinimi giderek artmaktadır. Paydaş Yönetimi Yaklaşımı, KSS ile temelinde yatan ahlaki hareket anlayışı ve paydaşlarla iletişimi sağlamadaki rolü nedeniyle birbiriyle ilişkili kavramlardır. Paydaş algılarını olduğu kadar davranışlarını da olumlu yönde etkileme gücü nedeniyle bu iki kavram birbirini desteklemekte ve etki gücünü arttırmaktadır. Paydaşların beklenti ve gereksinimleri doğrultusunda geliş̧tirilen KSS çalışmaları, işletme ile toplum adına çift yönlü bir kazanım elde edilmesine katk sağlayacaktır. Literatür taramasina dayanan bu çalışma ile KSS'ye halkla ilişskilerin temel ilkesi ve bütünleş̧tirici bir yönetim fonksiyonu olarak bakılmasının, Paydaş Yönetimi Yaklaşımı doğrultusunda işletmenin toplum tarafindan kabulünü sağlayan önemli ve gerekli bir araç olduğu savunulmaktadır.
\end{abstract}

\section{ANAHTAR KELIMELER}

Kurumsal Sosyal Sorumluluk, Paydaş Yönetimi Yaklaşımı, Halkla İlişkiler

\begin{abstract}
The need for businesses to act in line with social demands and pressures in order to gain legitimacy and to show that they are socially responsible citizens has led to an increase in the value given to Corporate Social Responsibility (CSR) studies. In addition to their responsibilities on accuracy, fairness and honesty, businesses have various responsibilities towards the environment, society and especially their stakeholders, and these responsibilities are increasing day by day. For this reason, businesses are expected to act in line with stakeholder expectations. In order to get the expected benefit from CSR activities, businesses need to put their stakeholders at the center as in line with the Stakeholder Management Approach, act according to the expectations and needs of their stakeholders, and support their CSR activities with the public relations practices. Stakeholder Management Approach and CSR is related concepts due to the moral action understanding underlying and its role in communicating with stakeholders. Stakeholder Management Approach and CSR support each other and increase their influence due to their power to positively affect stakeholder perceptions and behaviors. CSR studies developed in line with the expectations and needs of the stakeholders will contribute to a two-way gain for the business and the society. Based on a literature review, this study argues that considering CSR as the basic principle of public relations and an integrative management function is an important and necessary tool that ensures the acceptance of the business by the society.
\end{abstract}

\section{KEYWORDS}

Corporate Social Responsibility, Stakeholder Management Approach, Public Relations

\begin{tabular}{|c|c|c|}
\hline \multicolumn{2}{|r|}{$\begin{array}{c}\text { Makale Geliş Tarihi / Submission Date } \\
08.06 .2021\end{array}$} & $\begin{array}{c}\text { Makale Kabul Tarihi / Date of Acceptance } \\
22.11 .2021\end{array}$ \\
\hline Atıf & $\begin{array}{l}\text { Gedikçi Öndoğan, A. (2021). Paydaş } \\
\text { Halkla İlişkilerin Rolü. Selçuk Üniver }\end{array}$ & $\begin{array}{l}\text { oğrultusunda Kurumsal Sosyal Sorumluluk (KSS) ve } \\
\text { slek Yüksekokulu Dergisi, } 24 \text { (2), 528-539. }\end{array}$ \\
\hline
\end{tabular}

\footnotetext{
${ }^{1}$ Bu makale 3. Uluslararası Multidisipliner Sosyal Bilimler Kongresi kapsamında 4 Mayıs 2021 tarihinde gerçekleştirilen "Kurumsal Sosyal Sorumluluk Çalışmalarının Paydaş Perspektifinden Ele Alınması ve Halkla İlişkilerin Rolü” başlıklı sözel sunumun geliştirilmiş versiyonudur.

* Öğr. Gör. Dr., Selçuk Üniversitesi, ayse_gedikci@ selcuk.edu.tr, ORCID: 0000-0002-7933-9909
} 


\section{GİRIŞ}

Bilgi ve iletişim teknolojilerinde yaşanan hızlı gelişimin etkisiyle günümüz toplumsal yapısında bireysel beklentiler ve algılarda meydana gelen değişim, işletmelerin sorumluluklarının paydaş beklentileriyle doğru orantılı olarak artmasına neden olmuştur. Gelişen ve yaygınlaşan iletişim teknolojilerinin de etkisiyle görünürlüğ̈ artan işletmeler toplum üzerindeki etkileri nedeniyle yargılanmakta ve yaptıkları eylemlerden sorumlu tutulmaktadır. Özellikle etkinlik alanı genişleyen ve kullanımı giderek yaygınlaşan sosyal medya platformları sayesinde ürün ve hizmetleri yanı sıra söylem ve eylemleriyle de takip edilen işletmeler finansal performansı yanı sıra içinde yer aldığı topluma yaptığ katkılarla da değerlendirilmektedir (Kağnıcığlu, 2007: 2). İşletmelerden kurumsal çıkarlarını korumanın yanı sıra bir parçası olduğu topluma, çevreye ve sürdürülebilirliğe katkıda bulunmaları, belirli sosyal amaçlara sahip olmaları, sorunların çözümünde aktif olarak rol almaları ve iyi bir kurumsal vatandaş olmaları yönündeki beklenti giderek artmaktadır.

İşletmelerin sürdürülebilirliğinin insan hakları, iş gücü, çevre, yolsuzlukla mücadele gibi temel alanlarda sorumluluklarını yerine getirmelerine bağlanması ve sorumlulukların yerine getirilmesinde paydaş beklentilerinin öncelik teşkil ettiğinin belirlenmesi ${ }^{2}$, sosyal sorumluluklarını yerine getirirken işletmelerin paydaşlarını merkeze alarak onların beklenti ve gereksinimleri doğrultusunda hareket etme yönündeki eğilimini arttırmaktadır. Bu durum, toplumsal taleplere ve toplum yönlü bir baskıya yanıt aracı kullanılan KSS'nin, işletmenin paydaşları ile arasındaki anlayışı geliştiren, iletişimi kuvvetlendiren, paydaşları nezdinde konumunu güçlendiren, itibarını arttıran ve zor zamanlarında ona güç veren bir unsur olarak değerlendirilmesine neden olmaktadır (Leiva vd., 2016: 299).

Değişen toplum yapısının da etkisiyle toplumsal rolleri yanı sıra sorumlulukları da artan işletmeler birincil paydaş grupları olarak nitelendirilen hissedarları, çalışanları ve müşterileri yanı sıra hükümet, medya, çıkar grupları ve genel olarak halk (Mahon, 2002: 429) tarafindan izlenmekte ve sorumlulukların yerine getirme durumları takip edilmektedir. Bu durum, yaptıkları kadar yapmadıklarıyla da değerlendirilen işletmelerin varlıklarını devam ettirebilmek adına ekonomik ve yasal sorumlulukları yanı sıra etik ve toplumsal bağlamdaki sorumluluklarını da yerine getirme konusunda daha fazla çaba harcamaları ve eylemlerinin sorumluluğunu almaları noktasında daha dikkatli olmalarına sebep olmaktadır. İşletmelerden, ilişkide bulunduğu tüm paydaş gruplarına karşı yasal ve ahlaki değerlere uygun olarak hareket etmeleri, paydaş ve toplum menfaatlerini dikkate alan sorumlu işletme anlayışını benimsemeleri (Aktan ve Börü, 2007: 8; Ersöz, 2009: 131), kaynakları etkin ve verimli bir şekilde kullanarak, kaliteli üretim yaparak ve kâr elde ederek ülke ekonomisine katkıda bulunmaları (Peltekoğlu, 2014: 190), ürünlerin/hizmetlerin oluşumu ve sunumu noktasında toplum tarafindan beklenen hassasiyeti göstermeleri (Becan, 2011: 20), çevre sorunlarıyla ilgilenmeleri (Özüpek, 2005: 48-49) ve sorumlu bir davranış sergileyerek ihtiyaç sahiplerine sosyal desteklerini arttırmaları (Hohnen, 2007: 5) beklenmektedir. Bu bağlamda işletmelerin sürdürülebilir rekabet avantaj1 elde ederek değer yaratması için etkileşim içinde olsun olmasın tüm paydaş gruplarına karşı temel sorumluluklarını yerine getirmesi varlığını ve gelişimini etkileyen önemli bir unsur olarak karşımıza çıkmaktadır.

Bu çalışmada, işletme ile paydaşları arasındaki iletişimi sağlama ve karş11ıklı güven ortamını oluşturma açısından stratejik bir değere sahip olan KSS kavramı, yönetim literatürünün önemli bir bileşeni olan Paydaş Teorisi doğrultusunda şekillenen Paydaş Yönetimi Yaklaşımı ile ilişkisi açısından ele alınmaktadır. Literatür taramasına dayanan çalışmada, işletmenin paydaşlarıyla karşı1ıklı güvene dayalı bir iletişim ortamı oluşturması için paydaş beklentileri doğrultusunda uygulamalarına yön vermesi gereksinimi ile sürdürülebilirliğine ve toplum tarafından kabulüne ilişkin KSS çalışmalarının bir arada yürütülmesinin işletme ile toplum arasındaki iletişimin sürdürülmesinde önemli bir rol oynadığına vurgu yapılmaktadır. İşletmeye değer katması açısından paydaş beklentilerinin en doğru şekilde tespit edilmesi, amaca uygun çalışmalarının organize edilmesi ve paydaşlarla iletişimin geliştirilmesinde KSS'nin etkin bir şekilde kullanımının halkla ilişkilerin temel fonksiyonları olan tanıma ve tanıtım olgusunun sağlıklı bir şekilde gerçekleştirilmesi açsından gerekli olduğu ifade edilmektedir.

\section{KURUMSAL SOSYAL SORUMLULUK (KSS) KAVRAMI VE ÖNEMI}

Sorumluluk kelimesi sözlükte, "kişinin kendi davranışlarını ya da kendi yetki alanına giren herhangi bir olayın sonuçlarını üstlenmesi, sorum, mesuliyet"” olarak tanımlanmaktadır. "Bir kimsenin üzerine düşen görevleri yerine getirmesi ve kendisi tarafından gerçekleştirilen eylemlerin başkaları üzerindeki etkilerinin sonuçlarını üstlenmesi, başkalarının haklarına saygı göstermesi ve kendi davranışlarının sonuçlarına sahip çıkması" (Erdem, 2016: 350) durumunu ifade eden sorumluluk kavramı, bireylerin olduğu gibi

\footnotetext{
${ }^{2}$ The Ten Principles of the UN Global Compact. https://www.unglobalcompact.org/what-is-gc/mission/principles

${ }^{3}$ https://sozluk.gov.tr/
}

Selçuk Üniversitesi Sosyal Bilimler Meslek Yüksekokulu Dergisi, Yıl: 2021 Cilt: 24 Sayı:2 
işletmelerin de içerisinde yer aldığı toplumda belirli sorumluluklara sahip olması ve bu sorumlulukları yerine getirmek için çaba göstermesi durum olarak karşımıza çıkmaktadır.

Kurumsal sorumluluk, kurumsal hesap verebilirlik, kurumsal vatandaşlık, kurumsal etik ve sorumlu girişimcilik gibi pek çok kavramla birlikte anılan KSS (Hohnen, 2007: 4), sosyal açıdan bilinçli iş hareketinin bir göstergesi olarak iş ahlakı, kurumsal vatandaşlık, paydaş yönetimi ve sürdürülebilirlik gibi kavramlarla ilişkili ve örtüşen terim olarak nitelendirilmektedir (Carroll, 2015: 87). KSS, işletmelerin ekonomik ve yasal şartlara, ahlaki kurallara, kurum içi ve dışındaki kişi ve grupların yani paydaşlarının gereksinim ve beklentilerine uygun bir çalışma stratejisi benimsemesi (Çakırkaya, 2016: 138), bireyler ve toplum üzerindeki olumsuz etkilerini ortadan kaldırmak amaçlı bilgilendirme, gerekli ise kararlarından vazgeçme ve gelirinin bir kısmını olumlu sosyal amaçları desteklemek için kullanmaları ile ilgilidir (Dalyan ve Gökbel, 2005: 4). İşletmelerin kâr elde etmesinin ötesinde inandırıcı ve akla yatkın sebeplerle sosyal bir amaç için çalışarak, paydaşları nezdinde edindiği olumlu imajla kârlı bir şekilde büyüyebilmesidir (Fisk, 2010: 32). Sürdürülebilirlik anlayışı doğrultusunda yürütülen KSS çalışmalarının ekonomik, çevresel ve toplumsal alanlardaki beklentileri karşılamasının işletme ve paydaşlar nezdinde sağlayacağı fayda (TÍSK, 2016: 28) yanı sıra paydaşların kendilerini iyi hissetmelerinin sağlayacağı güçlü bir kurumsal itibarın işletmelerin daha uzun süre hayatta kalmalarını sağladığı belirtilmektedir (Kotler ve Lee, 2017: 10). "Halkın sorunlarına ve ihtiyaçlarına karşı görevler" (GfK, 2018) olarak da nitelendirilen KSS, işletmelerin ahlaki standartları takip etme, toplumsal beklentilere cevap verme, hayırseverlik çalışmaları yürütme ve paydaşlarıyla güvene dayalı ilişkiler geliştirmeleri noktasında daha aktif olmalarını sağlayan bir başarı göstergesi olarak değerlendirilmektedir (Akmeşe, 2017: 16).

Literatüre bakıldığında KSS kavramının gelişim sürecine paralel olarak farklı bakış açılarına göre şekillendiği görülmektedir (Yamak, 2007: 11). Genel olarak gönüllü uygulamalar ve işletme kaynaklarının kullanımıyla toplumsal refahın sağlanmasına yönelik üstlenilen bir sorumluluk olarak ifade edilen KSS (Kotler ve Lee, 2017: 2) işletmelerin faaliyetlerinden dolayı hesap verme durumu (Erdem, 2016: 352), toplumun genel refah düzeyini arttırmaya ve sürdürmeye yönelik çalışmaları ile paydaşlarını tanıma ve onların değerlerine saygı gösterme anlayışı (Aydınalp, 2013: 5) olarak tanımlanmaktadır. Bu tanımlamalara ek olarak, KSS çalışmalarının işletmenin hedefleriyle bağlantılı, sürdürülebilir uygulamalar olduğu (Jarolimek, 2016: 132); olumlu yönde değişim yaratabilme gücüne sahip olduğu (Bayraktaroğlu vd., 2009: 2); işletme için toplumsal ilişkilerin yürütülmesinde bir rehber niteliği taşıdığı (Köroğlu ve Ersöz, 2015: 130); çevreye karşı duyarlılığı ve ekonomik kalkınmayı arttırdığı belirtilmiş (Kağnıcıŏlu, 2007: 126); refah, sağlık ve emniyetin yanı sıra psikolojik ihtiyaçları da kapsayacak şekilde (Kotler ve Lee, 2017: 201) uzun vadede iş ve toplum ilişkisini sağlayan temel bir iş değeri stratejisi olarak bir politika dâhilinde ele alınması gerektiği ifade edilmiştir (Carroll, 2015: 89). Avrupa Komisyonu ${ }^{4}, \mathrm{KSS}^{\prime}$ 'nin AB işletmelerinin ve AB ekonomisinin sürdürülebilirliği, rekabet gücü ve gelişimi için önem taşıdığını ve risk yönetimi, maliyetlerden tasarruf, sermayeye erişim, müşteri ilişkileri, insan kaynakları yönetimi, operasyon yönetimi, inovasyon ve nihayetinde tüm bunları sağlayarak üretimi devam ettirmek yani kâr elde etmek için fayda sağladığını belirtmiş, KSS çalışmalarda paydaş beklentilerinin dikkate alınması gerektiğine vurgu yapmıştır. Sonuç olarak, işletmelerin sorumluluklarını yerine getirmesi, toplumun ahlak kurallarına ve geleneklerine uyması, çevresi için yardım ve destek sağlaması kendi meşruiyetini artıracak ve toplumsal bağlamda kabulünü sağlayacak önemli bir unsur haline gelmiştir (Kılınç, 2018: 233).

KSS'nin kapsamı ve işleyiş yapısı doğrultusunda literatürde çok sayıda ve birbirinden farklı boyutlara dikkat çekildiği görülmektedir. KSS yaklaşımının önemli temsilcilerinden yönetim Profesörü Archie B. Carroll (1979), KSS konusunda ortaya atılan farklı görüşleri bütünleştirmek amacıyla işletmelerin sosyal sorumluluklarının boyutlarını bir model içerisinde toplamıştır. Oluşturduğu modelle, yöneticilerin sosyal konular hakkındaki düşüncelerini sistematik hâle getirmeyi ve sosyal performans alanındaki uygulamalarına yardımcı olmayı amaçladığını belirten yazar, sorumlulukların sadece işletmenin değil aynı zamanda toplumun da yararını dikkate alacak şekilde ele alınması gerektiğini, toplumsal sorumluluğun boyutlarını ve bu boyutlara verilen tepkinin şekli ve önemi konusundaki görüşlerini de ortaya koymuştur (Carroll, 1979: 502-504). Carroll'ın Sosyal Sorumluluk Piramidi (1991) olarak adlandirılan modeli konuyla ilgili uygulama ve araştırmalarda en çok kullanılan modellerden biri olma özelliğini taşımaktadır. Literatürde kavramla ilgili farklı modeller olmasına rağmen yaygın olarak kullanılan modelde işletmelerin KSS uygulamaları ekonomik, yasal, ahlaki ve hayırsever sorumluluklar olarak dört temel alan içerisinde ve piramit bir yapıda derecelendirilmiş (Carroll, 1991: 42) ve tüm bu sorumlulukların aynı anda yerine getirilmesi gerektiğine vurgu yapılmıştır (Carroll, 2016: 5). Yani, işletmenin sosyal sorumluluklarını tam anlamıyla yerine

\footnotetext{
${ }^{4}$ https://ec.europa.eu/growth/industry/sustainability/corporate-social-responsibility_en
} 
getirebilmesi ancak kar elde etmesi, yasalara uyması, etik değerlere uygun hareket etmesi ve iyi bir kurumsal vatandaş olarak ihtiyaç sahiplerine destek vermesiyle sağlanabilir.

Schwartz ve Carroll (2003) önerdikleri $\ddot{U} c ̧$ Alanlı Model ile ekonomik, yasal ve ahlaki olarak üç merkezi KSS alanı arasında ilişkilerin daha eksiksiz ve doğru bir şekilde tasvir edilebileceğini belirtmiş ve hayırseverlik kategorisini ortadan kaldırarak onu ekonomik ve ahlaki alanlara dahil etmişlerdir. Schwartz ve Carroll'ın (2003: 525) Üç Alanlı Model'i, Carroll'ın (1991) piramit şeklinde ortaya koyduğu yapıdaki alanlar arasındaki hiyerarşik ilişkiyi ortadan kaldırılarak, iş dünyasında yaygın olarak kullanılan KSS çalışmalarını ve alana yönelimleri tanımlamanın alternatif bir yolu olarak gösterilmiştir. Ancak literatüre bakıldığında, Carroll'un daha sonraki çalışmaları da dahil (2015; 2016) pek çok araştırmada KSS boyutlarının dört temel alan üzerinden ele alınmaya devam edildiği görülmektedir. Bu durum hayırseverliğin her ne kadar diğer boyutlarla yakın ilişki içerisinde olsa da ayrı bir boyut olarak değerlendirilmesinin, işletmenin temel sorumluluklarını yerine getirdiğinin göstergesi olması açısından önem taşıdığ 1 ve toplumun işletmeden beklediği temel bir unsur olarak kabul edilmesi gerektiğini göstermektedir.

Carroll'a göre (2015: 90), ekonomik ve yasal sorumluluklar iş dünyası tarafından talep edilirken, ahlaki sorumlulukların yerine getirilmesi arzulanmakta ve hayırsever sorumluluklar ise toplum tarafindan beklenmektedir. $\mathrm{Bu}$ doğrultuda, KSS'nin alt boyutlardan ekonomik ve yasal sorumluluklara ilişkin tanımlamalar net bir şeklide karşımıza çıkarken, daha soyut değerler olan ahlaki ve hayırsever sorumluluklara ilişkin davranış kodlarının çok açık olmadığı, "yasal mevzuattan uzak olduğu” (Kara, 2019: 1), işletmenin vicdanına bırakıldığı (Aktan ve Börü, 2007: 16) ve aktivizm gibi toplumsal hareketler (Sert, 2012: 249) ile örf, adet, din ve kültürel yapıların baskıları (Özüpek, 2005: 17) haricinde genel anlamada bu sorumlulukların yerine getirilmesi konusunda baskı unsuru oluşturulamadığı görülmektedir. Bununla birlikte, işletmenin faaliyet gösterdiği topluma karşı geniş anlamada sorumlulukları olduğu ve bunları yerine getirilmesi gerektiği kabul edilmektedir (Carroll, 1979: 497; Coşkun, 2010: 41; Bonsu, 2019: 4; Dmytriyev vd., 2021: 1446). Ekonomik ve yasal sorumlulukların ötesinde işletmelerin paydaşlarına ve faaliyet gösterdiği çevreye zarar vermemesi, yasalarda belirtilmemekle birlikte uyulması gereken ahlaki değerlere uygun, doğru ve adil davranış sergilemesi (Demirtaş, 2015: 15), gönüllü olarak çevresel, sosyal ve toplumsal konulara destek olması (Carroll, 2016: 4), toplumsal sorunların çözümüne katkıda bulunması ve yakın çevresinden başlayarak ihtiyaç sahibi grupları gözetmesi gerektiği (Öndoğan, 2021: 298) ifade edilmektedir.

Literatürde KSS uygulamalarının geniş bir kapsama sahip olduğu görülmekle birlikte tipik olarak iki alanda yoğunlaştığı dikkati çekmekte ve bunlar (1) hayır işlerine katılarak iyilik yapma, gönüllülük ve toplum gelişimi ile (2) çevreye zarar vermekten kaçınma ve işçi hakları gibi çevresel ve sosyal boyutta sürdürülebilirliğe katk1 olarak özetlenmektedir (Dmytriyev vd., 2021: 1446). KSS'nin toplum refahı ile gelişimine ve bunun işletmenin sürdürülebilirliğine kattığı değerin anlaşılmasıyla (Bonsu, 2019: 15), kavramın ele alınmasındaki paydaş faktörünün önemi de giderek artmıştır. Paydaş yönetimi ve konu yönetimi gibi sosyal programlar dahilinde ele alınmaya başlayan KSS, işletme ile toplum arasındaki iletişimin sürdürülmesi, paydaş gruplarıyla işletme hedefleri doğrultusunda iş birliğinin sağlanması ve paydaş ilişkilerinin yönetiminde önemli bir aracı rolü oynamaya başlamıştır (Garriga ve Mele, 2004: 64).

\section{PAYDAȘ YÖNETIMİ YAKLAȘIMI İLE KSS İLIȘKİSI}

Adam Smith' in 1759 tarihli "The Theory of Moral Sentiments" ve 1776 tarihli "The Wealth of Nations" adl eserlerinde yer alan işletmenin ekonomik faydaları olduğu kadar toplumun etik değerlerinin de karşılandığı bir ilişki içinde ele alınmasıyla paydaş kavramının temelleri atılmış ve işletmelerin bu iki unsuru bir arada yürütebildiği sürece başarılı olacağı iddia etmiştir (Garriga ve Mele, 2004: 55). Edward Freeman'ın, 1984 tarihli "Strategic Management: A Stakeholder Approach" adlı eseri ise paydaş yaklaşımının öncü metin olarak kabul edilmektedir. Freeman (1984: 25), kitabında paydaş kavramını, "bir işletmenin amaç ve hedeflerine başarıyla ulaşmasını etkileyen ya da bu başarıdan etkilenen herhangi birey ya da grup" olarak tanımlamakta ve paydaş yaklaşımının temellerini değerlere dayalı yönetim, ekonomik olanın yanında siyasi, etik, sosyal ve çevresel kaygıların da dikkate alındığı bütüncül bir düşünce ve işletme ile paydaşlarının karşılıklı kazanımlarının teşvik edilmesi olarak özetlemektedir. Freeman'a göre (1984: 25) paydaşlar işletmenin hedeflerine ulaşmasında önemli bir role sahiptir, özellikle ikincil paydaş gruplarıyla olan ilişkiler ne kadar güçlü olursa işletmenin hedeflerine ulaşması o kadar kolay olacaktır.

İşletmelerin eylemleriyle diğer işletmeleri ve toplumu etkileyebileceği ve onlardan etkilenebileceğinin anlaşılmasıyla işletmenin açık sistem olarak dış çevre dinamiklerinden etkilendiği kabul edilmeye başlanmış ve bu durumun meydana getirdiği yönetim anlayışındaki değişiklikler 20. Yüzyılın ikinci yarısından itibaren KSS kavramının etkisinin tartışılmasına neden olmuştur. İşletmenin toplumsal bağlamdaki konumunu ve rolünü sorgulayan KSS kavramının Paydaş Teorisi gibi birçok teorinin temelini oluşturduğu ifade edilmiştir

Selçuk Üniversitesi Sosyal Bilimler Meslek Yüksekokulu Dergisi, Yıl: 2021 Cilt: 24 Sayı:2 
(Garriga ve Mele, 2004: 55). İşletmenin hedeflerine ulaşmasında etkili olan ve karşılıklı etkileşim halinde bulunduğu gruplar yanı sıra işletmenin sorumluluklarını yerine getirmesi noktasında hedef kitlesi konumunda olan (Freeman ve Dmytriyev, 2017: 10) ve desteği olmadan işletmenin var olamayacağı (Dmytriyev vd., 2021: 1444) paydaşlar arasındaki benzerlik ve farklılıkların tespit edilerek işletme menfaatleri doğrultusunda paydaş ilişkilerinin geliştirilmesinin işletme hedeflerinin başarısı açısından önemli bir gereklilik olduğu ifade edilmiştir (Mahon, 2002: 439).

Tüm paydaşların işletme için değerli ve eşit öneme sahip olduğunu ifade eden Paydaş Teorisi (Freeman ve Dmytriyev, 2017: 10) paydaş ilişkilerinin adalet, eşitlik, saygı gibi ahlaki ilkelerle yönetilmesi halinde çok daha fazla değer yaratacağına odaklanarak, bir işletmenin paydaşlarına nasıl davranabileceği veya davranması gerektiği ile davranışlarının hem işletme hem de paydaşları için ortaya çıkardığ tanımlamaktadır (Harrison ve Wicks, 2021: 405). Paydaş Teorisi, işletmenin, eylemlerinin başkaları üzerindeki etkilerinin sorumluluğunu alarak ekonomik ve etik yönlerden diğer insanlara karşı sorumluluklarını kabul etmekle ilgilidir (Dmytriyev vd., 2021: 1445). Paydaş Teorisi, temelde iki ana fikre dayanmaktadır: (1) paydaşlar, işletme faaliyetlerinden meşru menfaatleri olan kişiler veya gruplardır ki bunlar, işletmenin kendileriyle ilgili herhangi bir işlevsel menfaati olup olmadığına bakılmaksızın işletme üzerindeki menfaatlerine göre gruplandırılmalıdır ve (2) tüm paydaşların çıkarları özünde değer taşır, yani her bir paydaş grubu yalnızca hissedarlar gibi başka bir paydaş grubunun çıkarlarını koruma kapasitesi nedeniyle değil kendi iyiliği için değerlendirmeyi hak eder (Donaldson ve Preston, 1995: 67). Paydaş Teorisi doğrultusunda bir işletmenin varlığını devam ettirebilmesi için önemli olan, aktif ve sürekli destek alınması gereken ve diğer işletmelerin etkilemeye veya işletmeden ayırmaya çalışacağı birincil paydaş grupları (hissedarlar, tedarikçiler, çalışanlar ve müşteriler) ile işletmeyi dolaylı yoldan etkileyen ikincil paydaş grupları (hükümet, medya, kamu çıkar grupları ve genel olarak halk) arasında sistemli ve işletme hedefleri doğrultusunda maksimum iş birliğinin sağlanması için ilişkilerin doğru yönetilmesi, doğru stratejilerin kullanılması ve paydaş gruplarını etkileyen sorunların ele alınması Paydaş Yönetimi Yaklaşımı'nın temelini oluşturmaktadır (Mahon, 2002: 429).

Paydaş Yönetimi Yaklaşımı, işletmelerin paydaşlarının beklentilerini en iyi şekilde karşılamak amacıyla çalışmaların organize edilmesiyle ilgilidir. Garriga ve Mele'ye göre (2004: 59) Paydaş Yönetimi Yaklaşımı, doğrudan işletmenin paydaşlarına veya kurumsal politika ve faaliyetlerinden etkilenen veya onları etkileyen kişilere yöneliktir. Paydaş Yönetimi Yaklaşımı, paydaş ilişkilerinin ve en iyi uygulamaların belirlenmesi, yöneticiler için paydaşların önemi, paydaş yönetiminin finansal performansa etkisi, paydaş ilişkilerinin işletme yapısına etkisi ve yöneticilerin çeşitli paydaş gruplarının birbiriyle çelişen taleplerini başarılı bir şekilde nasıl dengeleyebileceği gibi konular üzerinden paydaşları yönetimsel karar alma sürecine entegre etmeye çalışarak kararların doğru alınmasında önemli bir rol üstlenmektedir (Clarkson, 1995: 92). İşletmenin paydaşlarının kimler olduğu, hangi riskleri ve firsatları barındırdığı ve mevcut durumla başa çıkmak için hangi strateji, eylem ve kararların alınması gerektiğinin ortaya çıkarılması noktasında işletme yönetimine yol gösteren Paydaş Yönetimi Yaklaşımı, paydaşların değer ve çıkar algılarının yönetimini de gerçekleştirerek, işletmeler tarafından tasarlanan ve belirli paydaş gruplarının çıkarlarına ters düşen uygulamaların zararlı ve/veya ahlaki açıdan sorunlu olarak algılanmasının yaratacağı olumsuz etkilerin önüne geçilebilmesini de sağlamaktadır (Harrison ve Wicks, 2021: 407). Paydaş Yönetimi Yaklaşımı işletmelerin faaliyette bulunduğu çevreyi anlamaya ve tüm paydaş gruplarının beklenti ve ihtiyaçlarını kapsayacak şekilde kârlılığını artırmanın ötesindeki sorumluluklarını yerine getirmeye yönelik bir araç olarak algılanmakta ve işletme ile paydaşları arasındaki iliş̧iyi inceleyerek, işletmenin paydaşlarıyla karşılıklı güvene dayalı bir ilişki kurması konusunda ona yol göstermektedir (Becan, 2011: 24).

Paydaş Teorisi ve KSS'nin ortak amaçlar gütmesine rağmen gelişim kaynakları açısından farklı bakış açılarına sahip olduğuna dikkati çeken Dmytriyev ve arkadaşları (2021: 1445), işletmeyi başarılı kılmayı amaçlayan Paydaş Teorisi'nin işletme ve yöneticilerinin bakış açısına göre gelişim gösterirken, daha iyi bir dünyayı hedefleyen KSS'nin toplum perspektifinden türetildiğini, toplumun ihtiyaçları ve beklentileriyle ilgili endişeleri temsil ettiğini, yani toplum kaynaklı bir gelişim sergilediğini savunmuştur. İşletmenin faaliyetlerini yürütme şekli ve özellikle de birincil ve ikincil paydaşlarıyla olan ilişkileriyle özdeşleşen KSS, Paydaş Teorisi ile ilişkilidir (MacMillan vd., 2004: 15). Bu ilişki, kavramların ortaya çıkış kaynakları farklı olsa da amaçlarının aynı olmasından ileri gelmektedir. Paydaşların tanımlanarak, işletmeye karşı sahip olduğu algının şekillendirilmesi ve işletmenin geleceğiyle ilgili olumlu düşüncelere sahip olmalarının sağlanması noktasında her iki kavram da birbirini olumlu yönde etkilemekte ve birbirinden etkilenmektedir. Clarkson (1995: 92), işletmelerin genel olarak toplumdan ziyade paydaş gruplarıyla ilişkileri yöneterek sosyal konular ile paydaş sorunları arasında ayrım yapmasının önemli olduğuna değinmiş, işletmenin memnun etmeyi amaçladığı paydaş gruplarının KSS çalışmalarında odak noktası olarak belirlenmesi ve bu grupların endişe ve sorunlarının 
göz önüne alınması gerektiğine vurgu yapmıştır. KSS ve Paydaş Teorisi 'ni birbirine derinden bağl iki kavram olarak ifade eden Freeman ve Dmytriyev (2017: 12), işletmelerin KSS ile toplumsal sorunlarla ilgileniyormuş gibi görünmek yerine gerçek anlamda paydaş sorunlarına değinerek yaptıkları katkının çok daha önemli ve değerli olduğunu belirtmiştir. Sonuç olarak hem Paydaş Teorisi hem de KSS işletme sorumlulukları açısından Friedman'ın (2007: 174) “işletmelerin sosyal sorumluluğu yoktur” şeklinde özetlenen yönetim anlayışının çok ötesine geçmesine neden olmuştur.

KSS işletmenin topluma karşı zorunlu olmamakla birlikte toplum tarafından talep edilen ve beklenen, daha çok ekonomik ve ahlaki boyuttaki yükümlülüklerini temsil ederken, Paydaş Teorisi doğrultusunda şekillenen Paydaş Yönetimi Yaklaşımı işletmenin sorumluluklarının paydaş grupları nezdinde ayrı ayrı tanımlanması ve adil olarak yerine getirilmesi gereğine vurgu yapmaktadır (Brown ve Foster, 2013: 301). Toplumsal talepler, işletmelerin KSS'ye ilişkin tutum ve davranışlarının oluşumunda belirleyici ve şekillendirici bir işlev üstlenebilmekle beraber, bu taleplerin işletmeler tarafından doğru bir şekilde algılanması ve eylemlere yansıtılması gerekmektedir (Kılınç, 2018: 257). İşletmeler açısından paydaş ilişkilerinin yönetilmesi sürecinde yaşanan zorluk ve KSS çabalarından beklenen yararın elde dilmesi beklentisi bu iki kavram arasındaki ilişkinin odak noktasını oluşturmaktadır. Rutin işleyiş içerisinde hangi paydaşların, hangi gereksinimlerinin dikkate alınacağına karar vermek ve çok sayıda paydaş grubu (hissedarlar, tüketiciler, çalışanlar, tedarikçiler, topluluklar, aktivist gruplar vb.) içerisinden seçim yapmak zor olabilir. İşletme yöneticilerinin, paydaş beklentilerinin aciliyetini ve önemini belirlemede kullandığ iki önemli kriter ise paydaşların işletme nezdinde sahip olduğu meşruiyeti ve işletmeyi etkileme gücü olarak gösterilmektedir (Carroll, 1991: 43). KSS çalışmalarının yerine getirilmesi açısından bakıldığında meşruiyet en önemli kriter olabilirken, Paydaş Yönetimi Yaklaşımı açısından bakıldığında paydaşların işletmeyi etkileme gücü en önemli kriter olarak ele alınabilmektedir.

KSS çalışmalarının başarıya ulaşmasında, mevcut politika ve süreçlerin sürekli olarak izlenmesi ve güncellenmesi, çevresel ve sosyal performansın değerlendirilmesi, paydaşlara sürekli olarak danışılması ve tüm paydaşlarla verimli iletişim ve etkileşim ortamı oluşturulması son derece önem taşımaktadır (Dilling, 2011: 30). İşletme hedeflerin gerçekleştirilmesinde kurumsal sosyal stratejinin temel unsurlarından biri olarak değerlendirilen paydaşlarla ilişkilerin geliştirilmesi için KSS çalışmalarından destek alınması hem ekonomik hem de sosyal bakımdan olumlu sonuçlara ulaşma ve rekabet avantajı elde etme açısından önemli görülmektedir (Filho vd., 2010: 297). İşletmenin kurumsal stratejisinin bir parçası olduğu kadar toplumun da bir parçası olan paydaşların, işletmeye zarar verme potansiyeli de göz önünde bulundurularak, KSS çalışmalarında hedef kitle olarak ele alınması ve tüm paydaş gruplarına beklenti ve gereksinimleri doğrultusunda adil ve etkili bir biçimde davranılması hem işletme hem de toplumsal refah adına önemlidir (Harrison ve Wicks, 2021: 415-416). Paydaş Yönetimi Yaklaşımı ile birincil paydaşlar hedeflerine ulaşırken, diğer paydaş gruplarının da memnun edilmesini sağlanarak her zaman mümkün olmasa da kazankazan sonucunun elde edilmesine odaklanılmaktadır. Uzun vadeli olarak kurumsal çıkarları korumak adına meşru/arzu edilen bir şekilde doğru hedefi belirlemek ve bu doğrultuda paydaşları analiz etmek, beklenti ve gereksinimlerini tespit etmek, anlamak ve stratejik bir politikayla KSS sürecini yönetmek hem işletme hem de toplum adına kazanım elde etmeyi sağlayacaktır.

\section{PAYDAŞ YÖNETIMI YAKLAŞIMI DOĞRULTUSUNDA YÜRÜTÜLEN KSS ÇALIŞMALARINDA HALKLA İLIŞKILERİN ROLÜ}

KSS'nin gelişiminde pek çok unsurun yanı sıra ticari açıdan önemli bir boyutu olduğu düşüncesi de etkili olmuştur (Chaffee, 2017: 373). Çevreye, paydaşlara ve toplumsal kalkınmaya yönelik ihtiyaç sahibi gruplara yapılacak çalışmaların işletmenin finansal performansı üzerinde olumlu sonuçlar doğurabileceği yönündeki kanıtlar işletmeleri daha çok sorumlu davranışta bulunmaya yönlendirmektedir. İşletmelerin kâr maksimizasyonunu arttırmasının hissedar ve yatırımcılarını memnun etmesiyle değil refah, kültür, eşitlik, adalet, hayırseverlik gibi alanlarda sosyal projeleri üretme, finanse etme ve uygulanabilir sosyal hedeflere sahip olmalarıyla mümkün olduğunun görülmesi (Perez vd., 2013: 462), KSS'nin daha profesyonel bir bakış açısıyla ele alınmasında etkili olmuştur. Bu durum, Paydaş Yönetimi Yaklaşımı doğrultusunda daha profesyonel bir bakış açısıyla ele alınan KSS çalışmalarının, halkla ilişkiler yöntem ve teknikleriyle desteklenmesinin işletme ile paydaşları ve dolayısıyla toplum ile arasındaki iletişimi kuvvetlendirmenin yanı sıra kurumsal bağlamda da önemli kazanımlara yol açacak bir olgu olarak değerlendirilmesini beraberinde getirmiştir. İşletmelerin meşruiyet kazanmak adına toplumsal talep ve baskılar doğrultusunda hareket etmesi ve sosyal açıdan sorumlu bir vatandaş olduğunu göstermesi gereksinimi ise halkla ilişkiler yöntem ve tekniklerinin kullanımına verilen değer ve önem düzeyinin giderek artmasına sebep olmuştur. 
Halkla ilişkiler uygulamaları toplumsal konular yanı sıra paydaşlarının değişen beklenti ve değerlerine göre değişiklik gösterebilmekle birlikte temel dayanağı paydaşlarla iletişim olduğundan iş dünyasıyla birlikte değişimini sürdürmektedir (Steyn, 2011: 4). Cutlip ve arkadaşları tarafından işletme ile paydaşları arasında karş11ıklı yarara dayanan ilişkileri kuran ve sürdüren bir yönetim fonksiyonu olarak tanımlanan halkla ilişkiler (Aktaran: Kalender, 2008: 24), güçlü mesajlar ve ikna edici iletişim yoluyla medyanın doğru ve ekin kullanımı, KSS uygulamalarında beklenen ilgi ve farkındalığın yaratılması, paydaşlara daha geniş bir yelpazeden erişim sağlanması gibi çok sayıda amaç doğrultusunda işletmeye fayda sağlayan bir unsur olarak değerlendirilmektedir (Kotler ve Lee, 2017: 51). KSS'nin hem toplum refahı hem de işletme menfaatleri doğrultusunda fayda sağlayan bir unsur olarak görülmesi, işletmelerin topluma karşı sorumluluklarını yerine getirme ve paydaşlarla ilişkilerini geliştirme kapsamında halkla ilişkiler yöntem ve tekniklerinden daha çok destek almalarına neden olmaktadır.

Paydaş Teorisi'nin merkezinde yer alan güven kavramının inşasında önemli bir yer teşkil eden halkla ilişkiler, işletme ve toplum arasında çift yönlü iletişim akışını sağlayan bir köprü görevi görmektedir (Göksel, 2013: 51). İşletmenin faaliyette bulunduğu çevreyi anlama ve paydaş gruplarının beklenti ve ihtiyaçlarını kapsayacak şekilde sorumluluklarını yerine getirmesine yönelik bir araç olarak algılanan Paydaş Yönetimi Yaklaşımı ise işletmenin paydaşlarıyla karşılıklı güvene dayalı ilişki kurmasını (Becan, 2011: 24) ve toplum tarafından kabulünü sağlamaktadır (Akdağ, 2007: 220). Ancak bu önemli aracın etkinliği, paydaş beklentilerinin doğru tespiti ve uygun yöntemlerle karşılanması için doğru iletişim tekniklerinin kullanımına ihtiyaç duymaktadır. Sosyal amaçlar güderek paydaşlarına ve dolayısıyla topluma destek vermek isteyen işletmelerin öncelikle onları tanıması, beklenti ve gereksinimlerini doğru tespit etmesi ve en uygun yöntemi kullanabilmesi için halkla ilişkilerin tanıma fonksiyonu doğrultusunda çalışmalar yürütmesi gerekmektedir. KSS uygulamalarıyla, belirlenen sosyal amaçlara ulaşmak için hedef kitleyi doğru seçmek ve onlar üzerinde işletmeye ilişkin olumlu bir alg1 oluşturmak işletme için hayati öneme sahip bir unsur haline gelmiştir (Gümüş ve Öksüz, 2009: 2131).

Halkla ilişkilerin işletme ve toplum arasındaki aracı rolünü ayna ve vitrin işlevleri olarak özetleye Van Riel (Aktaran: Steyn, 2011: 30), ayna işleviyle, işletmenin geleceğe uyum sağlamak için paydaşlardan eğilimlerle ilgili bilgi edindiğini, bu bilgiyi işlediğini, işletme içerisinde yayılmasını sağladığını ve çevresel etkilerden işletmeyi korumak için dışarıdaki gelişmeleri dikkate alarak bunları yaptığını belirtirken; vitrin işleviyle, işletmenin tüm yönlerini şeffaf bir şekilde yansıtan iletişim politika ve stratejisinin hazırlanması ve yürütülmesi için işletme dışına bilgiler iletilerek işletmeyi temsil ettiğini belirtmiştir. Halkla ilişkilerin bu iki temel işlevi, yani tanıma ve tanıtım olarak özetlenen fonksiyonları, KSS uygulamalarının hazırlık aşamasından sonuçların değerlendirilmesine kadar tüm safhalarında etkinliğini arttıran bir unsur olarak ele alınmalıdır. KSS ile halkla ilişkiler arasındaki ilişkinin önemine değinen Peltekoğlu ve Tozlu (2017: 28), KSS çalışmalarında halkla ilişkilerin sadece paydaşlarla iletişiminin sürdürülmesi ve uygulanmaların yapılması aşamalarında değil, aynı zamanda sosyal sorumluluk anlayışının kurum kültürünün bir parçası haline getirilmesi ve içselleştirilmesi, yönetim anlayışının bir parçası olarak benimsenmesi ve gönüllü katılımın sağlanması gibi aşamalarında da kapsayıcı bir rol oynadığına vurgu yapmıştır.

KSS çalışmalarının işletme menfaatlerini de kapsayan bir yaklaşımla çok yönlü olarak ele alınması ve paydaş beklentileri doğrultusunda uygulamalara stratejik bakış açısıyla bakılmasının işletmeye çok yönlü kazanımlar sağlayacağ 1 çok sayıda çalışma ile ortaya koyulmuş bir bulgudur. İşletmenin, paydaşlarına ve bir parçası olduğu topluma hizmet etmek amacıyla yaptığı KSS çalışmalarının işletmeye zarar verebileceği gerekçesiyle hayırseverlik bağlamında değerlendirilmesi gerektiği için halkla ilişkiler çalışmalarıyla duyurulmaması gerektiği yönünde (Özgener, 2000; Adıg̈zzel, 2014; Türker ve Vural, 2016) görüşlerin varlığına rağmen, işletmeye ve topluma sağladığı faydalar açısından önemle ele alınması ve halkla ilişkiler yöntem ve teknikleriyle desteklenmesi gerektiğini gösteren çalışmaların sayısı da giderek artmaktadır (Dalyan ve Gökbel, 2005; Gümüş ve Öksüz, 2009; Aksak vd., 2016; Peltekoğlu ve Tozlu, 2017; Hoştut, 2018; Mitra, 2021; Öndoğan, 2021).

Edward Bernays'ın "Halkla ilişkiler sosyal sorumluluğun uygulanmasıdır" şeklindeki ünlü sözü yanı sıra Grunig ve Hunt'ın işletmenin halkla ilişkiler işlevini yerine getirmesinin başlıca nedeninin sosyal sorumlulukları olduğuna dikkati çekmesi (Aktaran: Bakan ve Kalender, 2007: 346), KSS'nin yerine getirilmesinin halkla ilişkilerin temel ilkesi olduğunun vurgulanması açısından değerlidir. Burada KSS'nin yerine getirilmesi ile işletmenin gereksinim duyduğu halkla ilişkiler işlevinin yerine getirilmesi, yani halkla ilişkilerin bir araç rolü görmekten ziyade temel amaç olarak nitelendirilmesi önemlidir. İşletmenin paydaşlarını tanıması ve kendisini onlara daha iyi tanıtması için halkla ilişkileri kullanmasının, işletme normlarını paydaşlarına ileterek güç ve meşruiyet kazanma adına önemli bir araç işlevi göreceği (Aksak vd., 2016: 80) ve bu durumun KSS yanı sıra işletme performansı açısından da hayati öneme sahip olduğu ortaya konulmuştur 
(Mitra, 2021: 11). Bu bağlamda, halkla ilişkilerden KSS çalışmalarının uygulanmasında olduğu kadar işletmenin paydaşlarıyla iletişimi ve eylemlerinde karşılıklı anlayış, sempati ve güven kazanma açısından yararlanılması işletme çıkarlarına hizmet eden bir durumdur. KSS çalışmaları ile toplum nezdinde güven ve meşruiyetin kazanılması halkla ilişkilerin tanıma ve tanıtma fonksiyonlarının sağliklı bir şekilde kullanılmasıyla doğrudan ilişkilidir. İşletmenin, sosyal sorumluluk alanlarını ve hedef kitlesini $5 \mathrm{~N} 1 \mathrm{~K}$ prensibine uygun olarak belirlemesinden toplumda beklenen ilgi ve farkındalığın yaratılmasına kadar pek çok aşamada halkla ilişkiler yöntem ve tekniklerinden alınacak destek, Paydaş Yönetimi Yaklaşımı doğrultusunda belirlenen paydaş gruplarına, talep ve beklentileri doğrultusunda destek sağlanması açısından da oldukça önemlidir.

\section{SONUÇ}

Paydaş Yönetimi Yaklaşımı sosyal olarak sorumlu bir eylem içerisinde olan işletmelerin tüm paydaşlarının meşru çıkarlarını eşzamanlı olarak dikkate almasını gerektirmekte, sadece işletme açısından önem taşıyan hissedarlarının ve müşterilerinin değil işletmeyi etkileme gücü olan tüm paydaş gruplarının çıkarlarının dengelemesini zorunlu kılmaktadır. Toplum nezdinde fark yaratmak isteyen işletmelerin paydaşlarının ve dolayısıyla toplumun çıkarlarını savunarak fark yaratması ve sorumluluklarını yerine getirirken kurumsal çıkarlarını da koruyarak her iki tarafın da kazanç elde edebileceği bir denge sağlanabileceğinin anlaşılması KSS kavramının güçlenmesinde etkili olmuştur. Sorumlu davranışın göstergesi olarak yürütülen çalışmalar kadar bu çalışmaların kimler için ve hangi amaçla yapıldığı ve nihai hedefine ulaşıp ulaşmadığ1 konularının önemli hale gelmesiyle, kendisini paydaşlarının talep ve gereksinimleri doğrultusunda hareket eden iyi bir kurumsal vatandaş olarak göstermek isteyen işletmeler için KSS önemli bir araç işlevi görmeye başlamıştır.

İşletmelerin varlığını borçlu olduğu topluma karşı görev ve sorumluluklarını ifade eden KSS, işletme ve paydaşları arasında önemli bir iletişim kanalı rolü oynamaktadır. Daha çok gönüllü yükümlülükler, finansal olsun olmasın katkılar ve çeşitli uygulamalarla karakterize edilen KSS, işletmenin tüm paydaş gruplarına, topluma ve çevreye yaptığ 1 katkılar şeklinde kendini topluma tanıtma ve toplum üzerinde olumlu alg1 oluşturma işlevini görmektedir. Tüm işletme uygulamalarını kapsar tarzda konumlandırılması gereken KSS, finansal performans başta olmak üzere kurumsal imaj ve kurumsal itibar gibi çok sayıda kavramla olan ilişkisi nedeniyle farklı teori ve yaklaşımlarla birlikte ele alınmaktadır. Bunlardan biri olan Paydaş Yönetimi Yaklaşımı, KSS ile temelinde yatan ahlaki hareket anlayışı ve paydaşlarla iletişimi sağlamadaki rolü nedeniyle birbiriyle ilişki ve birbirini destekleyen kavramlar olarak gösterilmektedir.

Paydaş Yönetimi Yaklaşımı, tüm paydaş gruplarının ihtiyaç ve beklentilerini kapsayacak şekilde sosyal sorumlulukların yerine getirmesinde ve işletme ile paydaşları arasında karşılıklı güvene dayalı bir ilişki ortamı oluşturulmasında aracı görevi görerek paydaşlarının etkinliğini arttırma ve katılımcı karar alma yönünde işletmeye yol göstermektedir. Paydaşlarının çıkarları yönünde çalışmalar yürütürken aynı zamanda toplumsal açıdan kendisinden beklenen faydayı üreterek ve toplumsal talepleri karşılayarak kurumsal çıkarların korunmasına da yardımcı olan KSS, paydaş taleplerinin kurumsal stratejiye entegre edilmesiyle çift yönlü bir kazanım elde edilmesine katkı sağlayacaktır. İşletmenin sorumlu olduğu kişileri tanımlayan Paydaş Yönetimi Yaklaşımı, işletmenin tüm paydaş gruplarına karşı sorumluluğunu ifade eden KSS anlayışında, kaynakları sınırlı olan işletmenin hedefleriyle uyumlu bir şekilde kaynaklarını kullanmasına katkıda bulunacaktır. İşletme ve toplum menfaatleri doğrultusunda beklenen faydanın elde edilebilmesi için doğru hedeflerin belirlenmesi kadar yürütülen çalışmaların tanıtımının yapılarak toplumdan beklenen desteğin sağlanmasına imkân sunacaktır. Paydaş Yönetimi Yaklaşımı perspektifinden daha etkili ve çözüm odaklı bir yapıda ele alınan KSS, işletme ile paydaş/toplum iletişiminin devamlılığını sağlayarak ve temelinde yer alan adalet anlayışı nedeniyle tüm paydaş gruplarına eşit bir biçimde yaklaşarak farklı paydaş grupları arasındaki dengenin korunmasina da yardımcı olacaktır.

Halkla ilişkiler yöntem ve tekniklerinden alınacak destek, KSS bağlamında doğru çalışmanın, doğru zamanda ve doğru şekilde yapılması kadar mümkün olduğunca geniş kitlelere ulaşılması, amaçların doğru aktarılması, olumlu algı ve farkındalığın oluşturulması ile toplumda beklenen desteğin sağlanması açısından gereklidir. Bilişim teknolojilerinde yaşanan hızlı gelişimin etkisiyle günümüz toplumsal yapısında bireysel beklentiler ve algılarda meydana gelen değişim, işletmelerin sorumluluklarının paydaş beklentileriyle doğru orantılı olarak artmasına neden olurken, işletmenin paydaşları tarafindan daha yakından izlenmesine ve sorumluluklarını yerine getirme durumlarının kolaylıkla takip edilebilmesine de neden olmaktadır. Bu durum, yaptıkları kadar yapamadıklarıyla da değerlendirilen işletmelerin varlıklarını devam ettirebilmek adına paydaşlarına ve topluma karşı sorumluluklarını yerine getirme ve eylemlerinin sorumluluğunu alma konusunda olduğu kadar yaptıklarını duyurarak olumlu bir itibara sahip olma konusunda da daha fazla çaba

Selçuk Üniversitesi Sosyal Bilimler Meslek Yüksekokulu Dergisi, Yıl: 2021 Cilt: 24 Sayı:2 
harcamalarını gerektirmektedir. Paydaşların algılarını olduğu kadar davranışlarını da olumlu yönde etkileme gücü olan KSS ve halkla ilişkiler kavramlarının paydaş beklentileri doğrultusunda kullanılması hem yapılan çalışmaların etkisini arttıran hem de işletmenin sürdürülebilirliği açısından toplum nezdinde konumunu/itibarını güçlendiren bir faktör olarak değerlendirilmelidir.

$\mathrm{Bu}$ çalışmada KSS'nin işletme ile toplum arasındaki iletişimi kuvvetlendiren ve toplum tarafından kabulünü pekiştiren bir yönetim fonksiyonu olarak Paydaş Yönetimi Yaklaşımı doğrultusunda ele alınması, tüm paydaşlarla iletişimi kapsar tarzda geliştirilmesi ve halkla ilişkiler çalışmaları ile desteklenmesinin hem işletme hem de toplum menfaatleri doğrultusunda yarar sağlayacak bir unsur olduğu vurgulanmıştır. KSS çalışmalarından beklenen yararın ortaya çıkarılmasında yapılan çalışmaların paydaşlar nezdinde ortaya koyduğu değer kadar halkla ilişkiler ve tanıtım yöntemleriyle bilgilendirme ve farkındalık yaratma açısında desteklenmesinin de gerekli olduğu görülmüş̧ür. Paydaş beklentileri doğrultusunda ele alınan KSS çalışmalarına verilecek halkla ilişkiler desteği ile oluşturulacak güven ortamı ve memnuniyet duygusunun, yürütülen çalışmalarının başarıya ulaşmasında önemli bir aracı rolü görerek işletmenin paydaşları nezdinde kabulünü sağlayacak bir unsur olarak değerlendirilmesi gerektiği sonucuna varılmıştır. 


\section{KAYNAKLAR}

Adıgüzel, Adnan (2014). “İnsanlık Onurunu Koruma ve Kırma Arasında Hayırseverlik Anlayışı”, Eskişehir Osmangazi Üniversitesi İlahiyat Fakültesi Dergisi, I, s. 69-92.

Akdağ, Mustafa (2007). "Halkla İlişkilerde Sosyal Sorumluluk”. Tüm Yönleriyle Halkla İlişkiler ve Tanıtım (ed.) Metin Işık, Eğitim Kitabevi, Konya, s. 207-231.

Akmeşe, Halil (2017). Muhasebede Sosyal Yaklaşımlar, Eğitim Yayınevi, Konya.

Aksak, Emel Özdora, Ferguson, Mary Ann ve Duman, Şirin Atakan (2016). "Corporate Social Responsibility and CSR Fit as Predictors of Corporate Reputation: A Global Perspective". Public Relations Review, 42, s. 79-81.

Aktan, Coşkun Can ve Börü, Deniz (2007). "Kurumsal Sosyal Sorumluluk”. Kurumsal Sosyal Sorumluluk: İşletmeler ve Sosyal Sorumluluk (ed.) Coşkun Can Aktan, İGİAD Yayınları, İstanbul, s. 6-24. [Ekitap]. http://www.canaktan.org/yonetim/kurumsal-sosyalsorum/kurumsalsos-anasayfa.htm

Aydınalp, Güzin Ilıcak (2013). Halkla İlişkiler Ekseninde Kurumsal Sosyal Sorumluluk, Nobel Akademik Yayıncılık, İstanbul.

Bakan, Ömer ve Kalender, Ahmet (2007). "Halkla İlişkiler Bağlamında Kurumsal İtibar ve Sosyal Sorumluluk”, İletişim ve Ötesi. (ed.) Bilal Arık ve Mustafa Şeker, Tablet Yayınları, Konya, s. 345-370.

Bayraktaroğlu, Gül, İlter, Burcu ve Tanyeri, Mustafa (2009). Kurumsal Sosyal Sorumluluk: Pazarlamada Yeni Bir Paradigmaya Doğru, Literatür Yayıncılık, İstanbul.

Becan, Cihan (2011). "Kurumsal Sosyal Sorumluluk Kavramının Paydaş Teorisi ve İletişim Yaklaşımı Açısından Değerlendirilmesi: Bankaların Basın Bültenlerine Yönelik Bir İçerik Analizi”, Selçuk İletişim, 7 (1), s. 16-35.

Bonsu, Samuel (2019). "Corporate Social Responsibility: Assessing the Alignment of Theory and Practice Utilizing Case Studies", Journal of Marketing and Management, 10 (1), p. 1-18.

Brown, Jill A. ve Forster, William R. (2013). "CSR and Stakeholder Theory: A Tale of Adam Smith". J Bus Ethics, 112, p. 301-312.

Carroll, Archie B. (1979). "A Three-Dimensional Conceptual Model of Corporate Social Performance”, Academy of Management Review, 4 (4), p. 497-505.

Carroll, Archie B. (1991). "The Pyramid of Corporate Social Responsibility: Toward the Moral Management of Organizational Stakeholders", Business Horizons, 34 (4), p. 39-48.

Carroll, Archie B. (2015). "Corporate Social Responsibility: The Centerpiece of Competing and Complementary Frameworks". Organizational Dynamics, 44, p. 87-96.

Carroll, Archie B. (2016). "Carroll's Pyramis of CSR: Taking Another Look", International Journal of Corporate Social Responsibility, 1, p. 1-8.

Chaffee, Eric C. (2017). "The Origins of Corporate Social Responsibility”, University of Cincinnati Law Review, 85, p. 347-373.

Clarkson, Max B. E. (1995). "A Stakeholder Framework for Analyzing and Evaluating Corporate Social Performance". The Academy of Management Review, 20 (1), p. 92-117.

Coşkun, Gül (2010). Kurumsal Pazarlama ve Sosyal Sorumluluk, Nobel Yayın Dağııım, Ankara.

Çakırkaya, Murat (2016). İtibar Yönetimi: Perakende Sektöründe İtibar Yönetimi, Eğitim Kitabevi, Konya.

Dalyan, Figen ve Gökbel, Serpil A. (2005). İşletmelerde Sosyal Sorumluluk: İMKB'de İşlem Gören Bankaların Sosyal Sorumluluk Faaliyetleri ile Kârlılıkları Arasındaki İlişki, Anadolu Üniversitesi Yayınları, Eskişehir.

Demirtaş, Mine (2015). "Türkiye'de Yapılan Kurumsal Sosyal Sorumluluk Faaliyetlerinin Uluslararası Gelişmeler Bağlamında Değerlendirilmesi”, Kurumsal Sosyal Sorumluluk ve Kurumsal İtibar (ed.) Mine Demirtaş, Derin Yayınları, İstanbul, s. 1-54.

Dilling, Petra F.A. (2011). "Stakeholder Perception of Corporate Social Responsibility", International Journal of Management and Marketing Research 4 (2), p. 23-34.

Donaldson, Thomas ve Preston, Lee E. (1995). "The Stakeholder Theory of the Corporation: Concepts, Evidence and Implications". The Academy of Management Review, 20 (1), p. 65-91.

Dmytriyev, Sergiy D., Freeman, R. Edward and Hörisch, Jacob (2021). "The Relationship between Stakeholder Theory and Corporate Social Responsibility: Differences, Similarities, and Implications for Social Issues in Management”. Journal of Management Studies, 58 (6), p. 1441-1470. https://doi.org/10.1111/joms.12684.

Erdem, Hüsamettin (2016). "Ahlak ve Sorumluluk", Ahilik ve Meslek Ahlakı (ed.) Ömer Akdağ ve Meltem Kurtuluş, KTO Karatay Üniversitesi, Konya, s. 349-364.

Ersöz, Halis Yunus (2009). "Kurumsal Sosyal Sorumluluk". İşletmelerde İş Etiği (ed.) Sabri Orman ve Zeki Parlak, İstanbul Ticaret Odası, İstanbul (Yayın No: 2009-23), s. 131-170.

Filho, Jose Milton de Sousa, Wanderley, Lilian Soares Outtes, Gomez, Carla Pasa and Farache, Francisca (2010). "Strategic Corporate Social Responsibility Management for Competitive Advantage". Brazilian Administrario Review, 7 (3), p. 284-309. https://doi.org/10.1590/S1807-76922010000300006.

Fisk, Peter (2010). Sürdürülebilir Büyüme: İnsanlar, Gezegen ve Kâr (çev.) Eren Yıldırım, MediaCat Yayınları, İstanbul. Freeman, R. Edward (1984). Strategic Management: A Stakeholder Approach, Pitman: Boston.

Freeman, R. Edward ve Dmytriyev, Sergiy D. (2017). "Corporate Social Responsibility and Stakeholder Theory: Learning From Each Other". Symphonya Emerging Issues in Management, 1, p. 7-15. 
Friedman, Milton (2007). "The Social Responsibility of Business is to Increase its Profits", Corporate Ethics \& Corporate Governance (By Zimmerli, Walther Ch). Holzinger, Markus; Richter, Klaus. Berlin Heidelberg: Springer-Verlag. p. 173-178.

Garriga, Elisabet ve Mele, Domenec (2004). “Corporate Social Responsibility Theories: Mapping the Territory”. Journal of Business Ethics 53, p. 51-71.

GfK (2018). Kurumsal Sosyal Sorumluluk Araştırması. https://www.gfk.com/tr/icgoerueler/report/kurumsal-sosyalsorumluluk-arastirmasi-2018. Erişim Tarihi: 15.01.2021.

Göksel, Ahmet Bülent (2013). Stratejik Halkla İlişkiler Yönetimi, Nobel, Konya.

Gümüş, Murat ve Öksüz, Burcu (2009). “İtibar Süresinde Kilit Rol: Kurumsal Sosyal Sorumluluk İletişimi”, Journal of Yasar University, 4 (14), s. 2129-2150.

Harrison, Jeffrey S. ve Wicks, Andrew C. (2021). "Harmful Stakeholder Strategies”. J Bus Ethics 169, p. 405-419.

Hohnen, Paul (2007). Corporate Social Responsibility: An Implementation Guide for Business (ed.) Jason Potts, International Institute for Sustainable Development Canada. http://www.iisd.org/pdf/2007/csr_guide.pdf. Erişim Tarihi: 20.03.2021.

Hoştut, Sibel (2018). "Kurumsal Sosyal Sorumluluk İletişimi ve Halkla İlişkiler”, Gümüşhane Üniversitesi İletişim Fakültesi Dergisi, 6 (1), s. 101-128.

Jarolimek, Stefan (2016). "Kurumsal Sosyal Sorumluluk İletişiminde Ölçme Sorunları” (çev.) Seçil Deren Van Het Hof, Kurumsal Sosyal Sorumlulukta Güncel Yönelim ve Yaklaşımlar (ed.) Sibel Hoştut ve Seçil Deren Van Het Hof, Nobel, Ankara, s. 117-136.

Kağnıcıŏlu, Deniz (2007). Endüstri İlişkileri Boyutuyla Sosyal Sorumluluk. Anadolu Üniversitesi, Eskişehir.

Kalender, Ahmet (2008). "Halkla İlişkiler: Kavramlar, Tanımlar ve Uygulama Alanları”, Halkla İlişkiler (ed.) Ahmet Kalender ve Mehmet Fidan, Tablet Yayınları, Konya, s. 11-47.

Kara, Ayşe S. (2019). "Bir Halkla İlişkiler Aracı Olarak Kurumsal Sosyal Sorumluluk: Sosyal Refah için Araç mı Amaç mı?”, AURUM Sosyal Bilimler Dergisi 4 (1), s. 1-25.

Kılınç, İlknur (2018). “Kurumsal İtibar Açısından Sosyal Sorumluluk Uygulamaları: Türkiye’deki Çevreci Sivil Toplum Örgütleri Üzerine Bir Araştırma”. İletişim Kuram ve Araştırma Dergisi, 47, s. 229-261.

Kotler, Philip ve Lee, Nancy (2017). Kurumsal Sosyal Sorumluluk (çev.) Sibel Kaçamak, MediaCat Yayınları, İstanbul.

Köroğlu, Çağrı ve Ersöz, Hüseyin Önlem (2015). "Muhasebe Meslek Mensuplarının Bakış Açılarından Kurumsal Sosyal Sorumluluk Muhasebe İlişkisi”, Journal of Accounting, Finance and Auditing Studies, 1 (3), s. 123-153.

Leiva, Ricardo, Ferrero, Ignacio ve Calderon, Reyes (2016) "Corporate Reputation in the Business Ethics Field: Its Relation with Corporate Identity, Corporate Image, and Corporate Social Responsibility”, Corporate Reputation Review, 19 (4), p. 299-315.

MacMillan, Keith, Money, Kevin, Downing, Steve and Hillenbrand, Carola (2004). "Giving Your Organisation SPIRIT: An Overview and Call to Action for Directors on Issues of Corporate Governance, Corporate Reputation and Corporate Responsibility", Journal of General Management, 30 (2), p. 15-42.

Mahon, John F. (2002). “Corporate Reputation: Research Agenda Using Strategy and Stakeholder Literature”, Business \& Society, 41 (4), p. 415-445.

Mitra, Nayan (2021). "Impact of Strategic Management, Corporate Social Responsibility on Firm Performance in the Post Mandate Period: Evidence from India”. International Journal of Corporate Social Responsibility, (6) 3. https://doi.org/10.1186/s40991-020-00052-4

Öndoğan, Ayşe Gedikçi (2021). Kurumsal Sosyal Sorumluluğun Kurumsal İtibara Etkisi, Hiperyayın, İstanbul.

Özgener, Şevki (2000). “Ahlâk ve Sosyal Sorumluluk: İmalat Sanayinde Bir Uygulama”, Doktora Tezi, Selçuk Üniversitesi Sosyal Bilimler Enstitüsü, Konya.

Özüpek, M. Nejat (2005). Kurum İmajı ve Sosyal Sorumluluk, Eğitim Yayınevi, Konya.

Peltekoğlu, Filiz Balta (2014). Halkla İlişkiler Nedir? (8. Baskı), Beta Basım Yayım, İstanbul.

Peltekoğlu, Filiz Balta ve Tozlu, Emel (2017). "Halkla İlişkiler ve Gönüllülük Ekseninde Türkiye'de Kurumsal Sosyal Sorumluluk Projeleri ve Bin Yıl Kalkınma Hedefleri”. Selçuk İletişim, 10 (1), s. 5-31.

Perez, Andrea, Martinez, Patricia ve Rodriguez del Bosque, Innacio (2013). "The Development of a Stakeholder Based Scale for Measuring Corporate Social Responsibility in the Banking Industry", Service Business, 7(3), p. 459481.

Schwartz, Mark S. ve Carroll, Archie B. (2003). "Corporate Social Responsibility: A Three-Domain Approach”, Business Ethics Quarterly, 13 (4), p. 503-530.

Sert, Nuray Yılmaz (2012). Kurumsal Sosyal Sorumluluk ve Aktivizm İlişsisinin Araştırılması: Türkiye'de Özel Sektör, Kurumsal Sosyal Sorumluluk ve Aktivizm İlintisi. Doktotra Tezi, İstanbul Üniversitesi Sosyal Bilimler Enstitüsü, İstanbul.

Steyn, Benita (2011). "Değişen İş ve Halkla İlişkiler Paradigmaları”, Halkla İlişkilerden Stratejik Halkla İlişkilere, (ed.) Çiğdem Karakaya Şatır, Nobel, Ankara, s. 1-36.

TİSK (2016). Herkes İçin Kurumsal Sosyal Sorumluluk Projesi: Türkiye Sürdürülebilirlik Raporlaması Ulusal İnceleme Raporu. http://tisk.org.tr/wp-content/uploads/2016/04/CSR.pdf. Erişim Tarihi: 02.02.2021.

Türk Dil Kurumu Sözlükleri. https://sozluk.gov.tr/ (Erişim Tarihi: 07.08.2021).

Türker, Duygu (2009). “Measuring Corporate Social Responsibility: A Scale Development Study”. J Bus Ethics, 85, p. 411-427. 
Türker, Duygu ve Vural, Ceren Altuntaş (2016). "Kurumsal Sosyal Sorumluluk ve Hayırseverlik”, Kurumsal Sosyal Sorumlulukta Güncel Yönelim ve Yaklaşımlar (ed.) Sibel Hoştut ve Seçil Deren Van Het Hof, Nobel, Ankara, s. 149-170.

United Nations (T.y.). The Ten Principles of the UN Global Compact. https://www.unglobalcompact.org/what-isgc/mission/principles (Erişim Tarihi: 08.08.2021).

Yamak, Sibel (2007). Kurumsal Sosyal Sorumluluk Kavramının Gelişimi, Beta, İstanbul. 